Лембрик Л. Е. Соціальна психологія:[підручник] У 2 кн. Кн. 2: Соціальна психологія груп. Прикладна соціальна психологія / Л. Е. Орбан-Лембрик. - К. : Либідь, 2006. 560 с. 7. Основні чинні кодекси і закони України / Уклад. Ю. П. Слісовенко. - К. : Махаон, 2003. - 976 c. 8. The Studi of Primari Education. Compiled bu Colin Connerwith Brenda Lofthouse. - Second Edition. - London : RoutledgeFalmer, 1990. - Vol. 1: Perspectives. $-456 \mathrm{c}$.

УДК 351.361

Світлана Черевко

\title{
ПРОВЕДЕННЯ ОЦІНКИ ЦІЛЬОВОЮ ГРУПОЮ СВОЇХ ПОТРЕБ ЩОДО ЗДОРОВ'ЯЗБЕРЕЖЕННЯ
}

\author{
Черевко С. В. Проведення оцінки цільовою групою своїх потреб щодо \\ здоров'язбереження.
}

У статті описано метод оцінки цільовою групою своїх потреб щодо здоров'язбереження, фази проведення оцінки та результати. Доведено доцільність використання зазначеного методу зі студентами як цільовою групою. Акцентується на тому, що запропонований метод оцінки цільовою групою своїх потреб щодо здоров'язбереження носить ретроспективний та прогностичний характер і може використовуватися переважно для аналізу ситуацій з огляду на їх позитивний чи негативний уплив на життя цільової групи та кожного $з$ іiі членів. Метод оцінки цільовою групою своїх потреб щодо здоров'язбереження дає змогу окреслити як загальну проблему, так і окремі ії складники.

Ключові слова: здоров'язбереження, моніторинг, оцінка, метод оцінки цільовою групою своїх потреб щодо здоров'язбереження, фази, результати.

Черевко С. В. Проведение оценки целевой группой своих потребностей в отношении сохранения здоровья.

В статье описан метод оценки целевой группой своих потребностей по здоровьесбережению, фазы проведения оценки и результаты. Доказана целесообразность использования указанного метода со студентами как целевой группой. Акцентируется на том, что предложенный метод оценки целевой группой своих потребностей по здоровьесбережению носит ретроспективный и прогностичный характер и может использоваться преимущественно для анализа ситуаций с учетом их позитивного или негативного влияния на жизнь целевой группы и каждого из ее членов. Метод оценки целевой группой своих потребностей по здоровьесбережению дает возможность выделить как общую проблему, так и отдельные ее составляющие.

Ключевые слова: здоровьесбережение, мониторинг, оценка, метод оценки целевой группой своих потребностей по здоровьесбережению, фазы, результаты.

Tcherevko S. V. Assessing the Needs of the Target Group for Their Healthconsciousnes.

The article describes the method of assessing the needs of the target group for their health-consciousness, phases of evaluation and results. It is proved the feasibility of using this method with students as a target group. The attention is paid on the fact that the proposed method of assessing the needs of their target group for health-consciousness is retrospective and predictive in nature and can be used mainly for the analysis of situations based on their positive or negative impact on the lives of the target group and each of its 352

Педагогіка вищої та середної школи. - 2014. - Вип. 41 
members. Method of assessing the needs of the target group for health-consciousness makes it possible to delineate as a common problem, and some of its components.

Key words: health-consciousness, monitoring, assessment, the method of assessing the needs of the target group for their health-consciousness, phases, results.

В епоху глобалізації як на міжнародному, так і на національному рівнях пильна увага громадськості, у тому числі й наукової, приділена питанням здорового способу життя. Всесвітньоюорганізацією охорони здоров'я (далі- ВООЗ) визнано, що три тенденції, а саме: глобалізація, швидка непланова урбанізація та старіння населення планети - мають значний негативний уплив на погіршення здоров'я та поведінку людей $[1$, с. 10$]$.

На темі впровадження здоров'язбережувальних технологій у професійній діяльності фахівців різних напрямків зосереджена увага науковців і педагогівпрактиків (Т. Авельцева, ТБасюк, О. Безпалько, Т. Журавель, Н. Зимівець, Т. Лях, В. Молочний, С. Омельченко, Г. Радчук, А. Сущенко, Л. Сущенко, О. Тіунова, С. Харченко тощо).

Проте проблема потребує постійного розвитку, особливо в аспектах поєднання актуальної теорії і її впровадження в практичну роботу.

Метою статті є подання формату проведення оцінки цільовою групою своїх потреб щодо здоров’язбереження, опис фаз проведення оцінки та результатів.

Оцінку цільовою групою своїх потреб (ОЦГП) ми будемо розглядати як групу методів і підходів, що дозволяють людям визначати проблеми цільової групи, аналізувати їх та приймати рішення, які впливають на їх життя [2, с. 96].

Зважаючи на те, що ми працюємо зі студентами, нашою цільовою групою обрано сьогоднішніх студентів - завтрашніх фахівців, а найголовніше - молодих громадян України, від яких залежить майбутнє нації і держави. Саме тому вкрай актуальним $\epsilon$ питання покращення громадського здоров'я, а починати слід із ставлення як кожного громадянина, так і громади загалом до здоров'я і питань здоров'язбереження.

У сучасних умовах в аспекті реалізації соціальної політики у сфері здоров'я одним 3 іiі обов'язкових складників визначено проведення моніторингу та оцінки діяльності зі збереження і покращення громадського здоров'я.

Так, наприклад, міжнародним документом ВООЗ від 2009 року «Глобальна стратегія ВООЗ щодо харчування, фізичної активності та здоров'я: Керівництво для країн 3 моніторингу і оцінки здійснення» вперше гостро було поставлено питання щодо необхідності розроблення глобальних уніфікованих i стандартизованих інструментів, які б уможливили оцінку стану проблеми громадського здоров'я; види діяльності, спрямовані на розв'язання проблеми; якість та результати діяльності, перспективи тощо [3]. «Керівництво для країн з моніторингу і оцінки здійснення» стало всеохоплюючим засобом для управління зусиллями країн - членів ВОО3 у проведенні профілактичної роботи та детального представлення практичних заходів щодо сприяння фізичній активності та здоровому харчуванню.

Спочатку слід зазначити, що відстеженню процесів та результатів діяльності щодо здоров'язбереження громади чи певної цільової групи слугують такі процедури, як моніторинг та оцінка. Саме у зборі необхідної інформації для прийняття відповідних рішень і полягає їх сутність.

Відмінність між ними спрощено можна представити так: моніторинг дає відповіді на питання «ЩО?» (що зроблено, що робиться, що за проблеми / труднощі 
виникають, що за зміни відбулися чи відбуваються, що слід зробити тощо); оцінка відповідає на питання «НАСКІЛЬКИ?» (наскільки якісно, добре зроблено, наскільки сталі результати, наскільки значимі зміни, наскільки можна подолати труднощі тощо).

Завдання моніторингу - це виявлення проблемних місць задля коригування всього процесу [2, с. 45].

Оцінка - це процес детального аналізу результатів діяльності та їх співвіднесення 3 певними запланованими критеріями [2, с. 47].

Залежно від того, коли здійснюється оцінка, розрізняють вхідну (базову), поточну та підсумкову оцінки.

Науковці (Т. Басюк, О. Безпалько) констатують, що вхідна оцінка здійснюється на початковому етапі діяльності (або окремого виду роботи), коли потрібно оцінити вихідну ситуацію, реалістичність цілей та завдань, доречність та адекватність обраних об'єктів, очікуваних результатів [4, с. 81].

Поточну оцінку (оцінку процесу) застосовують під час упровадження окремих видів діяльності і коли, не очікуючи їх закінчення, необхідно оцінити відповідність діяльності тому. що було заплановано, необхідність у змінах, додаткових заходах. Отже, під час поточної оцінки оцінюються стратегії, заходи та ресурси діяльності.

Підсумкова оцінка - це оцінка результатів, яких досягнуто по завершенні сукупних видів діяльності. Отже, має місце аналіз кількісних і якісних показників, отриманих ефектів (соціальних, педагогічних, економічних тощо).

Зосередимо свою увагу на такому виді оцінки, як оцінка цільовою групою своїх потреб (скорочено - ОЦГП).

На основі розробок українського дослідника О. Безпалька [2, с. 97-98] нами виокремлено сім фаз проведення оцінки цільовою групою своїх потреб, а саме:

перша - формування груп з проведення оцінки цільовою групою своїх потреб та навчання методам ОЦГП (наприклад, ми формували групи респондентів з числа студентів і викладачів);

друга - визначення мети зазначеної оцінки - визначення очікуваного результату від ОЦГПта меж цільової групи (наприклад, виявити, у чому саме полягає проблема та рівень визнання цільовою групою іiі наявності. Ми оцінювали, чи вважають респонденти брак рухової активності шкідливим і загрозливим для здоров'я; чи вважають вони за необхідне для свого власного життя мати базові знання щодо здоров'язбереження, щонайменше з питань необхідної мінімальної рухової активності та здорового харчування);

третя - отримання підтримки значущого оточення (зустрічі 3 активістами цільової групи, представниками влади у сферах, що залучені довпровадження соціальної політики щодо здоров'язбереження; інформування громадськості- у своєму ВНЗ та широкої громадськості, тобто пересічного населення, - про ОЦГП);

четверта - планування проведення оцінки цільовою групою своїх потреб (йдеться про визначення інформації, необхідної для ОЦГП; визначення потенційних учасників ОЦГП та необхідних ресурсів);

п'ята - саме проведення оцінки (проведення ОЦГП у сформованих групах; виявлення можливих вторинних джерел інформації);

шоста - формування робочих груп (формування ініціативних груп зі студентства 3 розроблення та подальшого виконання планів щодо розв'язання проблем зі здоров'язбереження. Слід наголосити, що чинними навчальними програмами 3 навчальної дисципліни «Фізичне виховання» передбачено години на теоретичну підготовку. На основі визнаної статистики щодо стану здоров’я молоді, вважаємо за 
необхідне проводити як освітню діяльність, так і просвітницьку роботу 3 питань необхідної мінімальної рухової активності. Тут доцільними вважаємо не реферати, а інтерактивні форми навчання, які можна застосовувати під час теоретичної підготовки, а саме: тренінги, круглі столи, дебати тощо);

сьома фаза - інформування громади про результати оцінки цільовою групою своїх потреб (йдеться про інформування через ЗМІ, зустрічі/зібрання, форми та методи формальної та неформальної освіти: тренінги, семінари тощо).

Відповідно для кожної з фаз нами описано очікувані результати: фаза 1 сформовано групу зацікавлених осіб, знайомих із методами ОЦГП; фаза 2 - визначено мету ОЦГП; фаза 3 - отримано згодуцільової групи на проведення ОЦГП, широка громадськість у навчальному закладі знає про майбутню ОЦГП; фаза 4 - сплановано процес ОЦГП і створено всі необхідні умови для проведення ОЦГП; фаза 5 - виявлені та визначені проблеми зі здоров'язбереження за пріоритетністю; фаза 6 - сформовані робочі групи; фаза 7 - представники цільової групи та широкої громадськості у навчальному закладі поінформовані про результати ОЦГП.

Як приклад, поінформуємо про деякі дані, отримані в ході нашого дослідження. По-перше, слід ще раз акцентувати увагу на тому, що за твердженнями ВООЗ сьогодні проблема загрози здоров'ю як окремої особистості, так і всього людства розглядається як сьома додаткова до шести раніше визначених загроз планетарного масштабу (серед яких: загроза світової війни, нестача ресурсів планети, екологічні катаклізми тощо), а відсутність фізичної активності вважається четвертим 3 найголовніших факторів ризику, які $є$ причинами смертності в глобальному масштабі (6\% від загальної кількості випадків смерті у світі) [1, с. 10].

Ми провели опитування студенток першого курсу факультетів української, іноземної мови та мистецтвознавства Дніпропетровського національного університету ім. Олеся Гончара щодо їх ставлення до видів рухової активності. 3'ясували, що 3 опитаних респондентів не бажають взагалі займатися фізичною культурою 7\% респондентів. 91\% бажають займатися різними видами спорту, 82\% респондентів надають перевагу заняттям шейпінгу та аеробіки. Нібито статистика позитивна, водночас... Бажають займатися і займаються - це різні речі. Тому майже 70 \% мають хронічні захворювання, насамперед сколіоз. Важливо підкреслити також той факт, що $73 \%$ опитаних відмітили брак структурованої та готової для послуговування нею інформації з питань здорового харчування та стандартів необхідної мінімальної рухової активності, що сприяють збереженню здоров'я.

Отже, отримані нами в ході оцінки цільовою групою своїх потреб результати ще раз на рівні лише одного факультету одного з ВНЗ однієї з країн світу підтвердили наявність великої проблеми планетарного масштабу, виявлену дослідженнями ВООЗ, погіршення стану здоров'я людей на планеті, що потребує негайного втручання в зазначену проблему. Йдеться як про національні профілактичні просвітницькі програми зі сприяння здоров'ю, насамперед в аспектах фізичної рухової активності та здорового харчування, так і про базові освітні програми, зокрема 3 фізичного виховання. Проведена студентами як цільовою групою оцінка своїх потреб щодо здоров'язбереження підтвердила, що на рівні ВНЗ саме на заняттях 3 фізичного виховання слід імплементувати міжнародні рекомендації з рухової активності для здоров’я. Йдеться про Глобальні рекомендації з фізичної активності для здоров'я, запропоновані Всесвітньою організацією охорони здоров'я (ВОO3, 2004 рік). Саме це готові засвоювати наші студенти під час теоретичних i практичних занять. Як аргумент зазначимо, що розроблені ВООЗ для різних вікових груп рекомендації 
активно застосовують у багатьох країнах світу для формування й удосконалення компетентностей зі здоров'язбереження, для розроблення освітніх стандартів щодо здоров'язбереження.

У ході дослідження підтверджено доцільність використання методу оцінки цільовою групою своїх потреб щодо здоров'язбереження. Акцентуємо на тому, що запропонований метод оцінки цільовою групою своїх потреб щодо здоров'язбереження має ретроспективний та прогностичний характер i може використовуватися переважно для аналізу ситуацій з огляду на їх позитивний чи негативний уплив на життя цільової групи та кожного 3 iї членів. У процесі використання методу ОЦГП можуть бути окреслені як загальна проблема, так і окремі проблеми, що іiі складають.

\section{Література}

1. Global recommendations on physical activity for health / Глобальные рекомендации ВОЗ по физической активности для здоров'я [Електронний ресурс]. Режим доступу: http://whqlibdoc.who.int/publications/2010/9789244599976_rus.pdf// World Health Organization. - 2010. - 60 c. 2. Основи громадського здоров'я: теорія і практика: [навч.-метод. посібн.] / за заг. ред. О. В. Безпалька. - Ужгород : ВАТ «Патент», 2008. - 322 с. 3. Глобальная стратегия ВОЗ по питанию, физической активности и здоровью: Руководство для стран по мониторингу и оценке осуществления. - Всемирная организация здравоохранения. - Женева, 2009. - 47 с. Режим доступу: http:/whqlibdoc. who.int/publications/2010/9789244599976_rus. pdf. 4. Соціальна робота: Технологічний аспект: [навч. посібн.] / Держ. центр соц. служби для молоді; Ін-т соц. роботи та управління НПУ ім. М.П. Драгоманова; за ред. А. Й. Капської. - К., 2004. -364 с.

УДК 378.147

Наталя Чувасова

\section{ФОРМУВАННЯ КРЕАТИВНОЇ ПОЗИЦЇ̈ МАЙБУТНІХ УЧИТЕЛІВ ХІМЇ̈ ТА БІОЛОГІЇ У ПРОЦЕСІ ФАХОВОЇ ПІДГОТОВКИ}

Чувасова Н. О. Формування креативної позиції майбутніх учителів хімії та біології у процесі фахової підготовки.

У статті на основі зіставлення, порівняння, узагальнення наукової інформації феноменів «творчість», «креативність», «професійна позиція», «креативна позиція» розглядаються різні підходи до визначення цих понять. Виокремлено креативні якості, чинники, умови та етапи формування креативної позиції майбутніх учителів хімії та біології.

Ключові слова: креативність, творчість, творчий процес, професійна позиція, креативна позиція.

Чувасова Н. А. Формирование креативной позиции будущих учителей химии и биологии в процессе профессиональной подготовки.

В статье на основе сопоставления, сравнения, обощения научной информации феноменов «творчество», «креативность», «профессиональная позиция», «креативная позиция» рассматриваються различные подходы к определению этих понятий.

Ключевые слова: креативность, творчество, творческий процесс, профессиональная позиция, креативная позиция. 